\title{
Anabases
}

ANABASES Traditions et réceptions de l'Antiquité

25 | 2017

Varia

\section{Franz CUMONT, Astrologie}

\section{Antonio C.D. Panaino}

\section{OpenEdition}

\section{Journals}

\section{Electronic version}

URL: http://journals.openedition.org/anabases/6125

DOI: 10.4000/anabases.6125

ISSN: 2256-9421

\section{Publisher}

E.R.A.S.M.E.

\section{Printed version}

Date of publication: 1 April 2017

Number of pages: 282-284

ISSN: 1774-4296

\section{Electronic reference}

Antonio C.D. Panaino, "Franz cumont, Astrologie", Anabases [Online], 25 | 2017, Online since 01 April 2017, connection on 19 January 2021. URL: http://journals.openedition.org/anabases/6125 ; DOI: https://doi.org/10.4000/anabases.6125

This text was automatically generated on 19 January 2021.

(c) Anabases 


\title{
Franz CUMONT, Astrologie
}

\author{
Antonio C.D. Panaino
}

\section{REFERENCES}

Franz CUMONT, Astrologie. Volume édité par Danny Praet et Béatrice Bakhouche avec la collaboration d'Annelies Lannoy et d'Eline Scheerlinck, Bibliotheca Cumontiana, Scripta Minora - IV, Academica Belgica, Institut historique belge de Rome, Nino Aragno Editore, 2014, diffuseur Brepols Publishers, 416 p. + LVII, 75 euros / ISBN 978-90-74461-79-5

1 The publication of the fourth volume of the Bibliotheca Cumontiana, containing the minor works on astrology of the Belgian scholar, is certainly a very good piece of news for all the specialists of antiquity, Classicists and Orientalists as well. The interests and the researches of Cumont had in fact so many ramifications in different branches of the history of the ancient world that the present collection certainly will satisfy very many scholars who expected such a useful volume since a long time.

2 The present book contains 34 different articles of Cumont, whose pertinence ranges from Greek and Roman studies to Mesopotamia and Iran. The volume is opened by a short introduction entitled Projet éditorial (p. III-IV) by the Comité de rédaction, a Table des matières (p. V-VII), and a Préface (p. IX-XIV) by Danny Praet (Gent University). Then, the reader will find a useful Introduction aux Scripta Minora Cumontiana : textes sur l'astrologie (p.XV-XLI) by Béatrice Bakhouche (Université de Montpellier III), followed by another very pertinent introductory essay, entitled « Le problème de l'astrologie » dans le contexte idéologique de l'affaire Cumont : les relations entre religion et sciences dans l' Antiquité et dans les universités d'État belges (p. XLIII-LVII) again by Danny Praet. The volume is closed by two very good indexes, one of the names and of the ancient terms (p. 399-410) and a following one concerning the modern authors quoted in the articles (p. 411-416).

3 The importance of all the studies here collected is so deep that I do not dare to insist on their significance for the history of ancient studies ; the volume results certainly worth 
of attention by itself. The single articles have been re-edited (i.e. re-typed) in a way that permits to identify the original pagination thanks to a continuous reference to the original page that is put in square brackets. Furthermore, I must observe that also the choice of the single articles is absolutely sound. The editors prudently explain that in some cases the subject of some articles crossed the domain of different disciplines, so that the definitive arrangement in one or another volume of these Scripta Minora was not so easy, in particular when we consider that the full bibliography of Cumont contains 1028 (presently known) titles.

Thus, from this short presentation of the volume it is clear that we have to do with a remarkable collection, which will be indispensable in future studies on ancient astrology. But apart from these evident merits, I would like to dedicate few remarks on the introductory articles, which equally result of great interest.

5 The Préface by D. Praet gives a very exhaustive overview of the editorial project, which should contain seven thematic volumes, while most of the reviews, apparently more than 297, will be put at disposal of the readers on the public web-site of the Scripta Minora (see p.X, n. 3). This is certainly a very good decision that should increase the interest for the precious bibliographical material left by Cumont. This preface is also useful for the presentation of the complex editorial work endorsed by the academic and scientific board leading the whole project, and for a right recognition of the strong effort, also from the economic point of view, realized by some institutions as the Academia Belgica, the Institut historique belge de Rome, the FWO and the Universiteit Gent.

6 The following Introduction by B. Bakhouche proposes a historical key of interpretation of the astrological studies written in the course of his long career by Cumont for about 45 years (p. XVII). She shows how Cumont rewrote or modified some of his main contributions, in particular in occasion of new translations of his original studies in another language. B. Bakhouche rightly emphasizes the close connections between astrology and Oriental religions in the framework of Cumont's approach to the subject. This explains also his deep consideration not only for the fundamental work of A. Bouché-Leclercq (L'astrologie grecque, Paris 1899), but his strong cooperation with scholars like Franz Boll, Wilhelm Gundel, Georg Thiele, Fritz Saxl (p. XIX). This article is also of help when we try to frame the important relations of Cumont with prominent scholars like Arthur D. Nock and Joseph Bidez, relations which resulted very seminal, for instance with the second colleague, in the case of the publication of the Les Mages Hellénisés (2, vols., Paris 1938). Bakhouche's precious essay of interpretation is remarkably important for many aspects of Cumont's study of astrological matters, which cannot be discussed here in details, although I want to underline the correct observation that in Cumont "la sur-évaluation de l'héritage chaldéen est indéniable" (p. XXIII). I believe that nowadays the greatest effort in our work is that of trying to clarify or to identify in a more precise way what is really attributable to the Mesopotamian and/or Iranian world with respect to a generic and sometimes indistinguishable mass of Chaldaica that in many cases have nothing strictly Oriental. Contrariwise, we must also be careful avoiding to forget that some remarks are still sound, in spite of the fact that today they must be represented in a very different light and with a number of more precise data.

7 The third introductory article by D. Praet is a very intriguing contribution, because it sheds further light on the bold contrast that saw the Belgian Catholic minister of 
Education, Édouard Deschamps (1847-1933) refusing the designation of Cumont, at that time (1910) a young full professor of the University of Gand, as full professor of Roman history, chair for which he was chosen with the unanimous vote of his Faculty. The details of the affaire Cumont, on which already Corinne Bonnet has written a number of very pertinent papers, based on a number of first hand researches in the archives and on the epistolographical documentation still at disposal (p. XLIII-XLIV, n. 2), have been resumed and presented in a very balanced reappraisal of this sad event. As known, after a rude contrast, Cumont decided to resign (February 1910) from the University of Gand, but the article shows in a very clear way the international consideration already attributed to this scholar, who, in fact, was immediately invited to deliver a cycle of lectures in Uppsala by Nathan Söderblom, event to which a sort of intellectual tournée in the USA followed. In addition, Danny Praet focuses on the fact that the anticlericalism of Cumont never became a sort of anti-religious attitude, and that he simply insisted on the right to maintain a separation between science and politics, history of religion and theology.

\section{AUTHORS}

\section{ANTONIO C.D. PANAINO}

University of Bologna

antonio.panaino@unibo.it 